\title{
Correction to: Microstructure and mechanical properties of joints welded by friction-stir welding in aluminum alloy 7075-T6 plates for aerospace application
}

\author{
Mohammad Mohammadi-pour, Alireza Khodabandeh, \\ Sadegh Mohammadi-pour, Moslem Paidar* if
}

(c) The Nonferrous Metals Society of China and Springer-Verlag GmbH Germany 2017

Correction to: Rare Met.

DOI 10.1007/s12598-016-0692-9

The original version of this article was inadvertently published with incorrect references as below:

\section{Section 1:}

"Friction-stir welding (FSW) technology invented at The Welding Institute, UK, in December 1991 is a solid-state joining process for joining aluminum alloys and used increasingly in aerospace, transportation and car manufacturing industries $[1,2] . "$

\section{Section 3.2:}

"It can be said that the presence of threads on the pin enhances flow and mixing of materials. As expected, the absence thread on the pin restricts the material flow around the pin and subsequently reduces the WNZ area."

The online version of the original article can be found under doi:10.1007/s12598-016-0692-9.

M. Mohammadi-pour, A. Khodabandeh

Department of Materials Engineering, University of Islamic

Azad, Science and Research Branch, Tehran 14515775, Iran

S. Mohammadi-pour

Department of Materials Engineering, Amirkabir University of

Technology, Tehran 1387919343, Iran

\section{Paidar*}

Department of Materials Engineering, University of Islamic

Azad, South Tehran Branch, Tehran 1459853849, Iran

e-mail: M.paidar@srbiau.ac.ir
The correct reference is updated as below:

Reference "Thomas WM, Nicholas ED, Needham JC, Murch MG, Temple Smith P and Dawes CJ: Friction stir butt welding, 1991, US Patent 9125978.8." should be added as Ref. [3] to the above sentence in Section 1.

Reference "Eftekharinia H, Amadeh AA, Khodabandeh A, Paidar M. Microstructure and wear behavior of AA6061/ $\mathrm{SiC}$ surface composite fabricated via friction stir processing with different pins and passes. Rare Met. 2016, 492-493(4):1." should be added as Ref. [17] to the above sentence in Section 3.2.

And correspondingly all of the references should be reordered. 